\title{
Agronomic Performance of Different Cowpea (Vigna unguiculata (L.) walp) Varieties Cultivated as Sole and Intercropped with Maize in Chewaka District, South West Ethiopia
}

\author{
Sisay Legese ${ }^{1}$, Taye Tolemariam ${ }^{2}$, Kassahun Desalegn $^{3}$ \\ ${ }^{1}$ Department of Animal Science, College of Agriculture and Natural Resource, Assosa University, Assosa, Ethiopia \\ ${ }^{2}$ Department of Animal Science, Jimma University College of Agriculture and Veterinary Medicine, Jimma University, Jimma, Ethiopia \\ ${ }^{3}$ Department of Animal Science, Gondar University College of Agriculture and Veterinary Medicine, Gondar University, Gondar, Ethiopia
}

Email address:

sisbeddelle@gmail.com (S. Legese)

To cite this article:

Sisay Legese, Taye Tolemariam, Kassahun Desalegn. Agronomic Performance of Different Cowpea (Vigna unguiculata (L.) walp) Varieties Cultivated as Sole and Intercropped with Maize in Chewaka District, South West Ethiopia. Agriculture, Forestry and Fisheries.

Vol. 10, No. 2, 2021, pp. 75-84. doi: 10.11648/j.aff.20211002.16

Received: January 4, 2021; Accepted: January 18, 2021; Published: March 10, 2021

\begin{abstract}
Cowpea (Vigna unguiculata L. (Walp) is a legume crop grown for multipurpose uses. There are various varieties of cowpea grown under different agro ecologies throughout the world. The experiment was conducted at Chewacka district Buno Bedele Zone, South western Ethiopia; to identify adaptive and high yielding varieties under sole and cowpea maize based cropping system. The experimental contained 10 treatment combinations of sole Sewunet, sole Bole, sole Bekur, sole 9333, sole local, Sewunet + maize, Bole + maize, Bekur + maize, 9333+maize, local + maize. The treatment was arranged in a randomized complete block design (RCBD) with three replications. Data on performance during establishment and growth parameter were collected. The data were analyzed using Statistical Analysis Software (SAS version of 9.3). Results indicated that days to emergence, crop stand vigor, number of leaves/plant, number of branches/plant, plant height, days to $50 \%$ flowering, days to maturity showed significant variation $(\mathrm{P}<0.05)$ among cowpea varieties and cropping system. The highest numbers of leaves were recorded in sewunet (86.27) and Bole (81.93) in sole cropped cowpea, whereas, for cowpea intercropped with maize, the highest number of leaves (52.60) was recorded in Bole. On the other hand, the highest branch number was recorded from Sewunet (8.27) in sole cropped whereas; Bole recorded the highest branches in both sole (8.13) and intercropped with maize (5.2). Bole variety flowered early in both mono-cropped (49.67 days) and cowpea maize based cropped (55.33 days) whereas, Sewunet variety flowered late (62.67days) for mono-cultured and cowpea maize based cropped (66.67days). Bole variety had early pod setting both under sole (57.67) and maize intercropping (62.33), whereas, sewunet variety was late pod setting under sole (70.00) and when intercropped with maize (73.33). Bole variety was found to be superior in most parameters recorded when cultivated sole and intercropped with maize, so that, it can be integrated crops under the current land scarcity in Ethiopia. Further study is also important to see the effects of feeding cowpea forages on animal performances.
\end{abstract}

Keywords: Cowpea, Cropping System, Growth Performance

\section{Introduction}

Ethiopia is endowed with the largest livestock population in Africa with estimated domestic animal population of 57.83 million cattle, 28 million sheep, 28.6 million goat, 1.23 million camels, 60.5 million poultry, 2.1 million horses, 0.4 million mules and 7.88 million donkeys [13]. Along crops, livestock play an important role in food security as a source of food, skin, fiber, manure, dispensable capital and sociocultural stability to farmers of developing or under developed nations [10]. However, the productivity of the livestock resources and the benefits obtained from the sector is not related the livestock population due to various reasons such as poor nutrition and disease prevalence. Feed scarcity both 
in quantity and quality remains the bottleneck problem to animal performance in Ethiopia [41].

Population pressure forces expansion of farm sizes for agricultural crop production, and thus decreasing the grazing land from time to time [38]. This forces the animals to feed poor quality crop residue [44]. Consequently, improving the feed resource in particular and the production environment in general will improve the production and reproductive performance of livestock. The first option towards the improvement of the livestock production sub-sector in Ethiopia is improving the feed source base and feeding system. Dual purpose leguminous crops (food \& feed value) can serve as strategic supplements to other forage resources since they are rich in protein and minerals and also have the ability to enhance fiber degradation in the rumen [27]. Cowpea is among the major leguminous crop in Africa which accounts for over $95 \%$ of the global production, from which West Africa being the major regional producer. Cowpea has the potential to serve as a key legume species for increasing the crop and livestock production systems by supplying protein in human diets and fodder for livestock, as well as bringing nitrogen into the farming system through biological fixation [10, 9]. Its world annual production is estimated at 5,249,571 tons of dried grains of which over $64 \%$ is produced in Africa.

Combination of forage legumes into cereals production systems increase fodder production in quality and quantity which contributes to livestock directly which in turn improves the living standard of producers [29]. According to the reports across Africa on soybean-sorghum [24], cowpea-maize [16], sorghum-legume [6] and maize-legumes [40], intercropping systems have a higher yield than the sole cereal systems in semi-arid areas. The reason of yield benefit of intercropping are mainly that environmental resources such as water, light and nutrients can be utilized more efficiently in intercropping than in the respective sole cropping systems [28]. Chewaka district is one of the known mixed crop livestock production area and high potential area for livestock production especially on fattening. Evaluation of the agronomic performances of the cowpea at different cropping system is paramount importance at Chewaka district where improved forage development is limited and livestock depending on natural pasture and crop residues. Therefore, the general objective of this study was to determine agronomic performance of different cowpea (Vigna unguiculata (L.) Walp) varieties cultivated as sole and intercropped with maize in Chewaka district, South west Ethiopia, with the following specific objectives.

To evaluate the growth performance of cowpea varieties at Chewaka district.

To evaluate the effect of intercropping with maize on growth performance of different cowpea varieties in the study areas.

\section{Materials and Methods}

\subsection{Description of Study Area}

This study was conducted in Tarkanfata Misoma kebele of
Chewaka district during the 2017 cropping season (JuneSeptember). Chewaka district is located at $8.8^{0}-9.08^{\text {"N"N"}}$ latitude and 36-36.24" "E"longitude in Buno Bedele Zone of Oromia Regional State (Figure 1), at $559 \mathrm{~km}$ south west of Finfine and $72 \mathrm{~km}$ away from Bedele town. The altitude of the study area ranges from 900-1400masl. The area receives annual rain fall ranges from $1000 \mathrm{~mm}$ to $1200 \mathrm{~mm}$. The mean annual temperature ranges from 30 to $37^{\circ} \mathrm{C}$. The area is covered by variety of crops and natural vegetation. The dominant crops in the study area are maize, sorghum, rice, soya bean and seasame. The area coverage of the District is 35,680 hectares of which $52.60 \%, 19 \%$ and $28.40 \%$ hectares are cultivated, forest and grazing land respectively. The total livestock population in 2017 was estimated to be 35,766 head of cattle's, 48,351 head of goats, 7,692 head of sheep, 4,210 head of donkeys, 7 head of horses, $79.87 \%$ of local chickens and $20.13 \%$ of cross bred chickens. Mono-cropping is the dominant cropping practice in the district [11]. In the study area, maize is the leading cereal in area of cultivation and output or production. The trial was conducted on farmers training centers (FTC), which was selected because of its suitable topography of the field and proximity to roads.

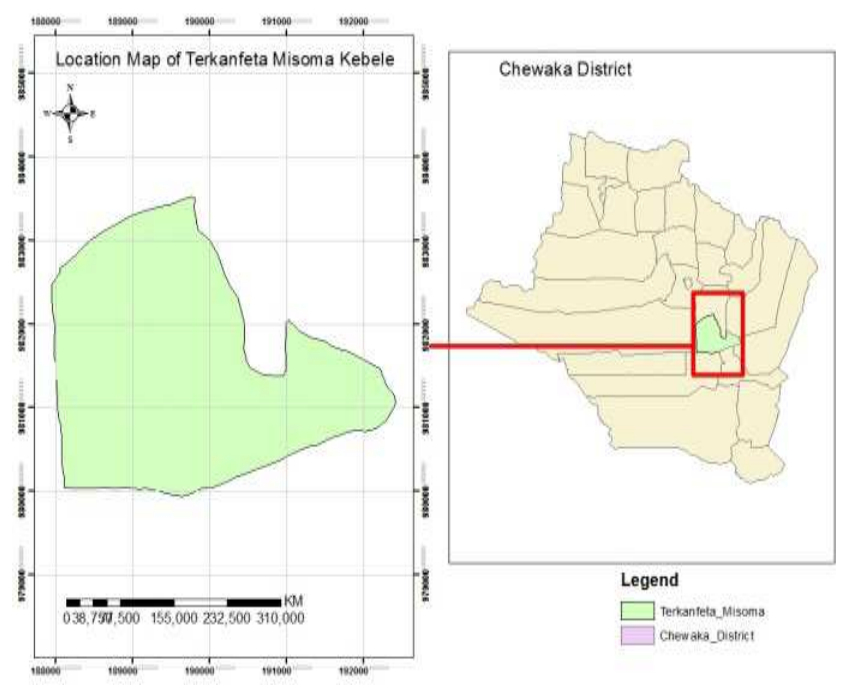

Figure 1. Map of the study area.

\subsection{Experimental Treatments}

The cowpea varieties Sewunet (IT 93KD 596), Bole (85D3517-2), Bekur (838 689 4), 9333 and local variety and one maize (30G19) variety were used for the study. The Genotypes, Bole, Bekur and 9333 were obtained from Adami Tulu Research center while, Sewunet variety was obtained from Jimma Research Center. Sewunet variety was released from Sirinka Agricultural Research Center SRARC/ARARI in the year of 2009, having determinate growth habit, pale rose and light red color of flower and seed respectively with altitude adaptation from 1000-1600masl and with rain fall of $700-1600 \mathrm{~mm}$. Its maturity date is 93 days after sowing with the yield potential $25 \mathrm{q} / \mathrm{ha}$ and $22 \mathrm{q} / \mathrm{ha}$ at research and farmers level respectively [30]. Bole variety was released from Melkassa Agricultural Center /EIAR in 2006 having 
determinate growth habit and altitude of 1300-1850masl which adapted to rain fall of $350-1100 \mathrm{~mm}$ with a maturity of 86-95 days. Its yield potential at research and farmer was 19 $\mathrm{q} /$ ha and $17 \mathrm{q} /$ ha respectively. Bekur variety was released from Pawe Agricultural Research Center /ARARI in 2001 having determinate growth habit, 94.5 days to maturity after sowing with the yield potential of $19-21$ and $19.6 \mathrm{q} / \mathrm{ha}$ at research and farmers field respectively. The varieties are adapted to an altitude range of 1450-1850asl with the rain fall of more than 660-1025 $\mathrm{mm}$ in growing season.

\subsection{Experimental Design}

The experimental treatments of Sewunet, Bole, Bekur, 9333 and local cowpea varieties and one maize (30G19) variety were arranged in randomized complete block design (RCBD) with three replications. The plot size of each plot for sole cowpea cropped was $7.2 \mathrm{~m}^{2}(2.4 \mathrm{~m} * 3 \mathrm{~m})$. The spacing between row and plants was $40 \mathrm{~cm}$ and $20 \mathrm{~cm}$ respectively. A foot path of $0.5 \mathrm{~m}$ and $1.5 \mathrm{~m}$ was left between plots and the blocks respectively. Each rows of the plot had 15 holes or plants and each plot had 90 plants and total plots of the three blocks contain 1350 plants. Plot size for cowpea and maize intercropping was $3 \mathrm{~m} \times 3 \mathrm{~m}\left(9 \mathrm{~m}^{2}\right)$. Each plot had four rows of maize with the distance of $75 \mathrm{~cm}$ and $25 \mathrm{~cm}$ between row and plant respectively at seed rate of $25 \mathrm{~kg} / \mathrm{ha}$. Cowpea was sown between maize rows.

Table 1. Experimental treatments.

\begin{tabular}{lll}
\hline Treatments & Variety & Replications \\
\hline 1 & Sole Sewunet & 3 \\
2 & Sole Bole & 3 \\
3 & Sole Bekur & 3 \\
4 & Sole 9333 & 3 \\
5 & Sole Local & 3 \\
6 & Sewunet + Maize & 3 \\
7 & Bole + Maize & 3 \\
8 & Bekur + Maize & 3 \\
9 & $9333+$ Maize & 3 \\
10 & Local + Maize & 3 \\
Total & & 30 \\
\hline
\end{tabular}

\subsection{Experimental Procedures}

The experimental field was ploughed three times by oxen, disked and harrowed to get fine seed bed before sowing. Sowing was done on June 20, at Tarkanfata Misoma farmer training center (FTC). For sole cowpea, seed sowing was done in rows with the distance of 40 and $20 \mathrm{~cm}$ between rows and plants respectively. However, for intercropped cowpea, maize was planted at first in rows. Spacing between an intra and inter-rows of maize were $25 \mathrm{~cm}$ and $75 \mathrm{~cm}$ respectively. Then, the cowpeas were under sown three weeks later after sowing of maize [1]. Recommended fertilizer rate $(100 \mathrm{~kg}$ $\mathrm{DAP} / \mathrm{ha}$ ) was used equally for all treatments [9]. However, nitrogen fertilizer was not applied to all cowpea based treatments. The outer most two rows on each side of the plot was left as border row and the four middle rows were used for data collection and yield measurement for sole cropped cowpea, whereas, the three middle rows were used for data collection for cowpea intercropped with maize. Weeding was done three times manually (hand weeding method) starting from three weeks later after sowing as well as insect pest and disease controls were conducted for all experimental plots as required.

\subsection{Data Collection and Measurement}

Days to emergence was recorded as number of days from date of sowing to the day when the majority $(90 \%)$ of the planted seeds have emerged just above the ground [4].

Stand vigor was also taken by visual observation from 1 to 5 scale $(1=$ the weakest, or least vigorous and $5=$ the strongest, or most vigorous).

Stand count per plot at 20,40, and 60 days after sowing (DAS) was also done to assess the establishment performance [19].

Data on Growth parameters

Plant height

The height of plants was recorded from ten randomly selected plants per plot from the ground to the tip of the plants at each sampling period in $\mathrm{cm} \mathrm{[4].}$

Number of branches per plant: this was determined by counting the total number of branches from the main stem of ten randomly selected plants in each plot.

Number of leaves per plant

Number of leaves per plant was determined by counting total number of leaves from ten plants of each plot.

Days to forage harvesting: Days to forage harvesting was counted from days to planting to the date when plants reach $50 \%$ flowering stage [4].

Days to $50 \%$ flowering: was determined by counting from days to planting to the date when $50 \%$ of the plants flowers.

Days to pod setting: was determined from days to planting to the date when the plant starts to set the pods.

Days to maturity: was determined from days to planting to the date when the plant fully matured.

\subsection{Statistical Data Analysis}

Data were subjected to Analysis of Variance using SAS software (SAS, 2009 version 9.3).

The following general model was used for analysis:

$$
Y i j=\mu+T i+B j+e i j, \text { where, }
$$

Yij= measured response of treatment $\mathrm{i}$ in block $\mathrm{j}$, $\mu=$ grand mean of the experiment,

$\mathrm{Ti}=$ effect of treatment $\mathrm{i}$,

$B j=$ effect of block $j$,

eij $=$ random error effect of treatment $\mathrm{i}$ in block $\mathrm{j}$.

\section{Results and Discussion}

\subsection{Establishment Performance of Cowpeas}

Days to emergence was longest $(\mathrm{P}<0.05)$ for Sewunet both in sole crop (T1) and when intercropped with maize (T6) than all the varieties either in sole crop or in intercropping 
(Table 2). The differences in days to emergence between study varieties were due to varietal difference of cowpea. However, Bilatu reported non-significant difference between cowpea varieties studied in days to emergence [10]. On the other hand, there was no significant difference in days to emergence between varieties by cropping system. The similarity in days to emergence in cropping system might be due to absence of competition of resources between the companion crops and no canopy effect of maize during cowpea emergence. On the other hand, Hailemariam reported variations in the days of emergence among the treatments and he stated that, the sole cowpea had lower days to emergence as compared to Sudangrass cowpea mixture which had late emerging dates due to the growing nature of the legumes as well as the canopy effect of the Sudangrass [20].

There were no significant differences $(\mathrm{P}>0.05)$ among the different varieties and treatment combinations in stand count at 20,40 and 60 days after sowing. The reason of non significant difference between varieties in number of seedling per treatments might be due high adaptability of the varieties to the area. On the other hand, there was significant difference $(\mathrm{P}<0.05)$ in stand vigor among the varieties of cowpea and cropping system at 20,40, and 60 DAS. At 20 DAS, the highest stand vigor was recorded in Sewunet variety (3.27), followed by Bole (3.25) and Bekur (3.00) whereas, the lowest stand vigor was recorded in $9333(2.80)$ and local (2.90) for cowpea sowed at pure stand. During 40DAS, Bole recorded the highest value (3.50) and local showed the lowest value (3.10) of stand vigor under sole cropped. The highest result of stand vigor at 60DAS was observed in Sewunet (4.47) followed by Bole (4.37) and the lowest was recorded in 9333 (3.82) for sole cowpea sown. But, for the intercropping, the highest stand vigor at 20, 40, and 60 was recorded in Bole+maize $(2.73,3.00,3.57)$ and the lower stand vigor was recorded in local+maize $(2.15,2.5$,

\section{8) respectively.}

The reason for different in stand vigor for intercropping cowpea with maize might be due to high competition for the limited growth resources. The value of stand vigor increased as the age of plant increased in both sole and intercropped cowpea. According to the report of Fekede, high germination rate, vigorous development and dense establishment are among the desired characteristics for forage crop variety [17]. Aikins and Afuakwa also reported that uniform and complete emergence of vigorous seedlings positively impacts the overall production of an annual crop by allowing the establishment of better canopy structure and providing time and spatial advantages to compete with weeds [2]. Establishment performance of different cowpea varieties was presented in (Table 2) and (figure 2) respectively.

Table 2. Establishment performance of different cowpea varieties in sole and intercropped.

\begin{tabular}{|c|c|c|c|c|}
\hline \multirow{2}{*}{ Treatments } & \multirow{2}{*}{$\begin{array}{l}\text { Days to } \\
\text { emergence }\end{array}$} & \multicolumn{3}{|l|}{ Stand count } \\
\hline & & 20 DAS & 40 DAS & 60 DAS \\
\hline $\mathrm{T} 1$ & $9.67 \pm 0.35^{\mathrm{a}}$ & $89.67 \pm 0.33$ & $88.67 \pm 0.67$ & $87.33 \pm 0.33$ \\
\hline $\mathrm{T} 2$ & $7.67 \pm 0.33^{b}$ & $89.67 \pm 0.33$ & $88.67 \pm 0.88$ & $87.67 \pm 0.33$ \\
\hline $\mathrm{T} 3$ & $7.67 \pm 0.33^{b}$ & $89.33 \pm 0.67$ & $88.67 \pm 0.88$ & $88.00 \pm 0.33$ \\
\hline $\mathrm{T} 4$ & $7.67 \pm 0.33^{b}$ & $89.67 \pm 0.33$ & $88.33 \pm 0.33$ & $87.33 \pm 0.33$ \\
\hline T5 & $7.67 \pm 0.33^{b}$ & $89.33 \pm 0.67$ & $88.00 \pm 0.58$ & $87.33 \pm 0.33$ \\
\hline T6 & $9.67 \pm 0.35^{\mathrm{a}}$ & $89.33 \pm 0.67$ & $88.00 \pm 0.58$ & $87.00 \pm 0.58$ \\
\hline $\mathrm{T} 7$ & $7.67 \pm 0.33^{b}$ & $89.33 \pm 0.33$ & $89.00 \pm 0.58$ & $87.00 \pm 0.58$ \\
\hline $\mathrm{T} 8$ & $7.67 \pm 0.33^{b}$ & $89.67 \pm 0.33$ & $88.33 \pm 0.67$ & $87.67 \pm 0.33$ \\
\hline T9 & $7.67 \pm 0.33^{b}$ & $89.67 \pm 0.33$ & $88.00 \pm 0.58$ & $87.33 \pm 0.33$ \\
\hline $\mathrm{T} 10$ & $7.67 \pm 0.33^{b}$ & $89.33 \pm 0.67$ & $88.33 \pm 0.33$ & $88.00 \pm 0.33$ \\
\hline Mean & $8.30 \pm 0.18$ & $89.50 \pm 0.47$ & $88.47 \pm 0.61$ & $87.47 \pm 0.38$ \\
\hline $\mathrm{P}$ - value & $<0.0001$ & 0.98 & 0.97 & 0.31 \\
\hline
\end{tabular}

Means with the same letter in the same column are not significantly different $(\alpha=0.05)$.

$\mathrm{T} 1=$ Sewunet, $\mathrm{T} 2=$ Bole, $\mathrm{T} 3=$ Bekur, $\mathrm{T} 4=9333, \mathrm{~T} 5=$ local, $\mathrm{T} 6=$ Sewunet + maize, $\mathrm{T} 7=$ Bole + maize, $\mathrm{T} 8=$ Bekur + maize, $\mathrm{T} 9=9333+$ maize, $\mathrm{T} 10=$ local + maize, $\mathrm{DAS}=$ Days after sowing.

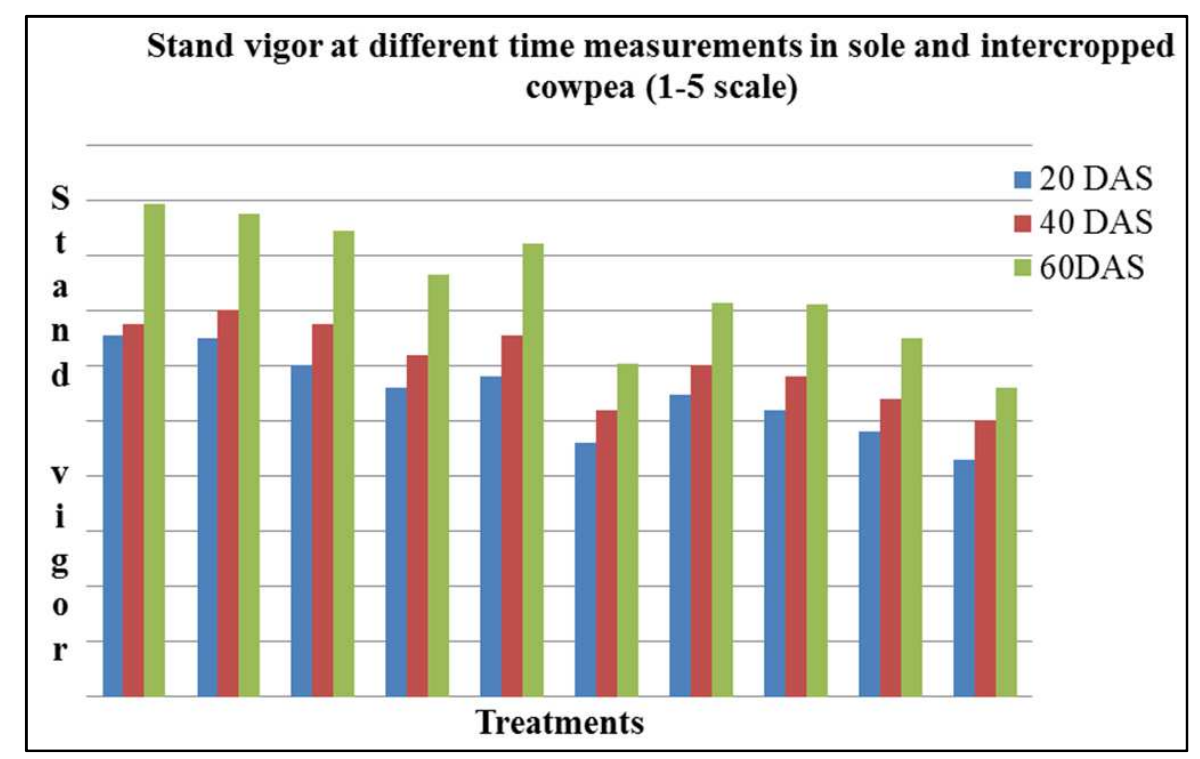

Figure 2. Stand vigor of different cowpea varieties at different time of measurements in sole and intercropped with maize.

$\mathrm{T} 1=$ Sewunet, $\mathrm{T} 2=$ Bole, $\mathrm{T} 3=$ Bekur, $\mathrm{T} 4=9333, \mathrm{~T} 5=$ local, $\mathrm{T} 6=$ Sewunet + maize, $\mathrm{T} 7=\mathrm{Bole}+$ maize, $\mathrm{T} 8=\mathrm{Bekur}+\mathrm{maize}, \mathrm{T} 9=9333+\mathrm{maize}, \mathrm{T} 10=1 \mathrm{ocal}+\mathrm{maize}$, vigor scale1-5 ( $1=$ very small; $2=$ small; $3=$ medium; $4=$ large and $5=$ very large. 


\subsection{Growth Parameters of Cowpeas}

\subsubsection{Plant Height}

Plant height was significantly affected $(\mathrm{P}<0.05)$ by varieties and cropping system at all measured days after sowing (Figure 3). The highest plant height during 20, 40, and 60 days after sowing was recorded in Sewunet variety $(16.20-\mathrm{cm}, 75.47-\mathrm{cm}$, and $122.10-\mathrm{cm})$, whereas, the lowest plant height was recorded in $9333(10.70-\mathrm{cm}, 39.13-\mathrm{cm}$ and $56.37-\mathrm{cm}$ ) for mono-cultured cowpea respectively. For intercropped cowpea with maize, the highest plant height at 20, 40 and 60 DAS, was observed in sewunet + maize $(12.87 \mathrm{~cm}, 60.97 \mathrm{~cm}, 85.67 \mathrm{~cm})$ and the lowest value of plant height was recorded in local+maize $(7.73 \mathrm{~cm}, 30.87 \mathrm{~cm}$ and $40.73 \mathrm{~cm}$ ) respectively (Figure 3 ). For all treatments, the mean plant height increased with the advancement of plant growth.

Increased in plant height might be attributed to either an increased in node number or internodes length or both. Plant height increased at a rapid rate from 20 to 40 DAS and the rate of increase decreased afterwards. Generally, the highest plant height was recorded in sole cowpea than cowpea intercropped with maize. The maximum plant height in case of sole crop was attributed to penetration of light, circulation of air and comparatively more nutritional area available to sole crop under competition free environment. Difference in plant height between cowpea varieties obtained in the present study was in agreement with the report of Kelechukwu who reported that cowpea height is varietal dependent as certain varieties are taller than others [26].

Decreased in plant height in intercropped situation, was ascribed to the fast growth of intercrops at an early growth stage and competition by intercrop for different environmental resources which suppressed growth of the companion crop. This result is in agreement with the finding of Ndiso who reported that, in Kilifi, sole cowpea had significantly higher plant height than intercropped cowpea while Lamu-cowpea intercrop system had the least cowpea plant height [33]. However, Hamd Alla found that cowpea intercropped with maize had significantly higher plant height compared to sole sowing [21].

\subsubsection{Numbers of Leaves per Plant}

Numbers of leaves per plant was significantly different $(\mathrm{P}<0.05)$ between varieties and cropping system at 20,40 and 60 DAS (Figure 3 ). The highest leaf numbers per plant was found in Sewunet variety (22.93) which was statistically similar with Bole (21.40) and Bekur (20.53), whereas, the lowest number of leaves per plant was observed in 9333 (14.27) varieties in sole cropped cowpea during 20DAS. On the other hand, at the period of 40DAS, the highest leaf number per plant was observed in sewunet (63.33) followed by bole (60.53) whereas, the lowest number of leaves per plant was recorded in local (47.97). During 60DAS, the highest number of leaves per plant was recorded in Sewunet (86.27) which is statistically similar with Bole (81.93) and the lowest number of leaf per plant was recorded in 9333
(65.87) in mono-cultured cowpea. The higher number of leaves per plant in Sewunet and Bole varieties might be attributed to its higher nutrients absorbing capacity due to its root system as compared to other tested varieties. This agreed with findings of Sebetha who reported the higher number of leaves per plant in Red caloona may be attributed to its higher nutrients absorbing capacity due to its root system as compared to Pan 311 in Limpopo [36].

Whereas, in case of intercropped cowpea with maize at 20DAS, statistically there was no significant difference between all cowpea varieties in number of leaves. At 40DAS, Bole + maize recorded the highest number of leaves per plant (42.73), whereas, Sewunet+maize recorded the lowest number of leaves per plant (31.87). During the period of 60DAS, the highest numbers of leaves per plant was recorded in Bole+maize (52.60) which is statistically similar with Bekur+maize (48.27) and the lowest numbers of leaves per plant was recorded in local +maize (40.40). However, statistically, there was no significant difference between Sewunet+maize, 9333+maize and local+maize respectively. Variation in number of leaf under intercropped might be attributed to the response of growth habit of the varieties used in different cropping system. Productivity of the intercrop can be enhanced by selection of cultivars suitable for intercropping as they differ in growth durations and habitats and which may result in different interactions when intercropped with maize.

The data reveals that, number of leaves per plant increased at a rapid rate from 20 to 40 DAS and the rate of increase decreased afterwards. Hence, growth performance in number of leaves per plants were $18.76 \%$ to $26.73 \%$ at $20 \mathrm{DAS}$, $42.77 \%$ to $62.47 \%$ at $40 \mathrm{DAS}$ and $18.77 \%$ to $28.69 \%$ 60DAS in both sole and cowpea maize based intercropped. The rate of growth in number of leaves per plant in general, was found to be reduced after 40 DAS. This might be because of leave shedding due to senescence and maturity of the crop. This result indicated that, numbers of leaves per plant were increased at higher rate during the period of 40DAS, but, the rate was almost equal at both 20 and 60DAS.

The significant difference in numbers of leaves per plant between mono-cropped cowpea might be due to varietal difference. These finding was supported by the finding of Singh who reported that spreading and semi-spreading cowpea varieties differ in their potential growth and development which can positively affect the yield of the crop [37]. The result of the present finding was also in agreement with the finding of Haruna, and Usman who observed a significant difference in growth and yield characters of some improved varieties of cowpea at the same location and attributed it to genetic make-up of the varieties examined were spreading varieties produced more number of leaf and this means more photosynthetic area; higher radiation interception and dry matter accumulation for utilization and production of the yield [22]. Though the yield obtained from mono-crop system was significantly higher, the system did not take into account the advantages associated with 
intercrops when a farm holding is small.

Maize has been shown to be more competitive than cowpea in terms of use of resources mainly soil water. When intercropped with maize, the radiation intercepted by maize leaves reduces considerably the energy input at the cowpea canopy level which is necessary for photosynthesis, possibly accounting for the low leaf vegetable and grain yields obtained in intercropped compared to sole crop regime. Similarly, the study done by Hauggaard-Neilsen have shown reduced individual crop yields under intercropping compared to sole cropping system of cowpeas [23].

\subsubsection{Numbers of Branches per Plant}

Numbers branches per plant was significantly affected $(\mathrm{P}<0.05)$ by varieties and cropping system at 20,40 and 60 days after sowing (Figure 3). During 20 days after sowing, the highest number of branches per plant was found in Sewunet (3.8) which is similar with Bole (3.67) whereas, Bekur, 9333 and local were recorded statistically similar number of branches per plant. In under sown cowpea, during 20 DAS, the highest number of branches per plant was observed in Bole+maize (2.4) and the lowest was recorded in local+maize (1.47). During the period of 40DAS, Bole recorded the highest (6.47) and 9333 recorded the lowest (4.53) number of branches per plant for sole cropped, whereas, Bole+maize recorded the highest number of branches (4.00) and local+maize recorded the lowest branches (2.4) for cowpea maize intercropped respectively.

At 60 DAS, the highest numbers of branches per plant was recorded in Sewunet (8.17) which is statistically similar with Bole (8.13) and the lowest numbers of branches per plant was recorded in 9333 (5.87) for sole sown cowpea, whereas, for intercropped, the highest numbers of branch per plant was recorded in Bole +maize (5.20) and the lowest numbers of branches was recorded in local+maize (3.60). The higher number of branches in Sewunet and Bole might be because the varieties were able to utilize edaphic factors such as fertility of the soil for yield maximization and environmental factors such as temperature [3].

Number of branches per plant increased at a rapid rate at 20 DAS and the rate of increased at decreased afterwards. Anjum reported that the number of branches per plant increased progressively during successive growth period of the cowpea up to 90 DAS under the influence of different treatments [8]. The variation in number of branches for mono-cultured cowpea might be attributed to the varietal difference between the studied cowpea. This result was supported by the result of Ali and Ichi, who were reported that significant difference in number of branches per plant was as a result of varietal difference in cowpea varieties [5, 25].

For all treatments, the number of branches per plant was higher in sole cropped cowpea than cowpea intercropped with maize. Reduction in numbers of branches per plant in intercropping cowpea and maize was due to shading by the taller maize plants which might have resulted in reduction of vegetative growth. According to Egbe, intercropping depressed the number of branches per plant and the dry grain yield of cowpea when compared to sole cropping system [14]. Reduction in the number of branches also reported by Gabir who stated that, the differences in number of branches per plant could be due to competition between sorghum and cowpea and due to shading by the taller sorghum plants which might have resulted in reduction of vegetative growth [18]. Cowpea plant height, number of leaves and number of branches per plant at different time measurements are presented in (Figure 3).
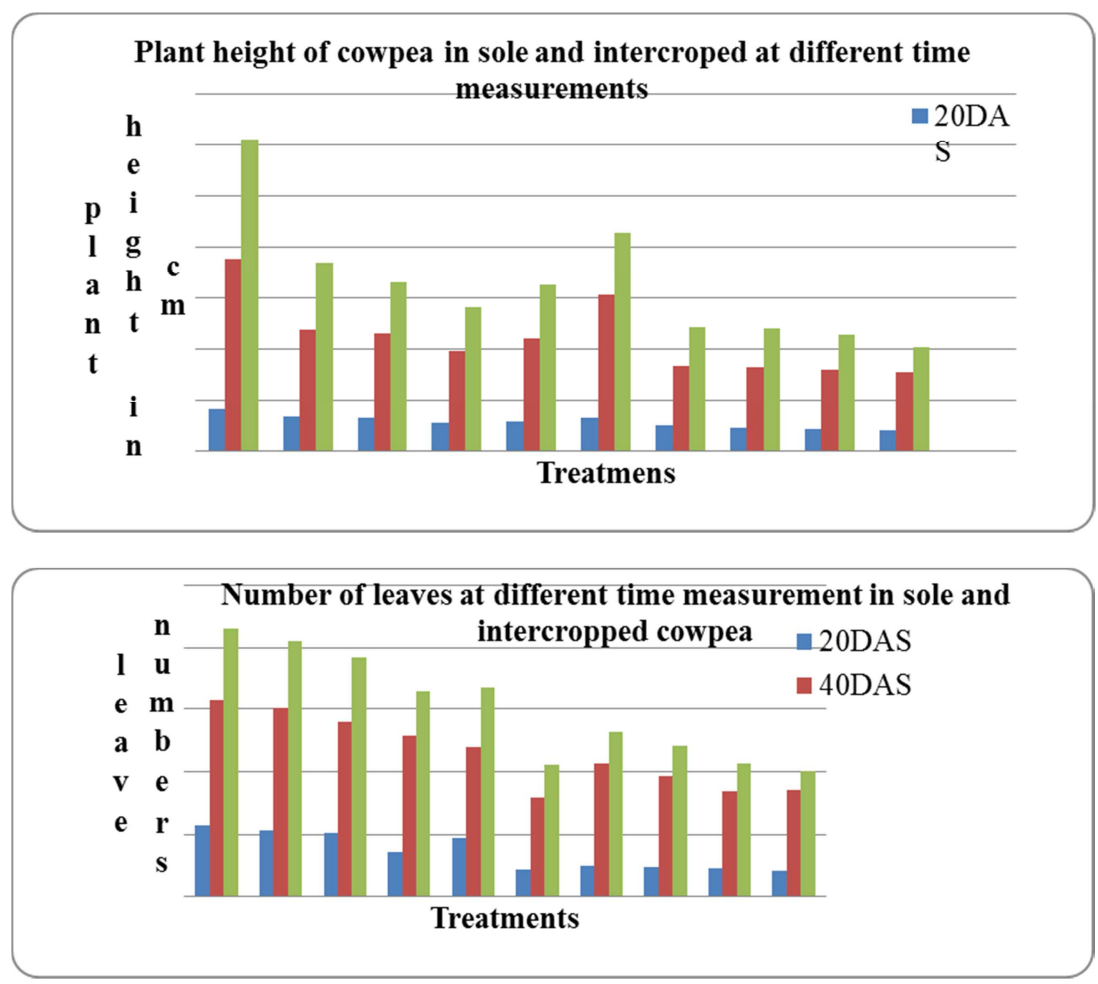


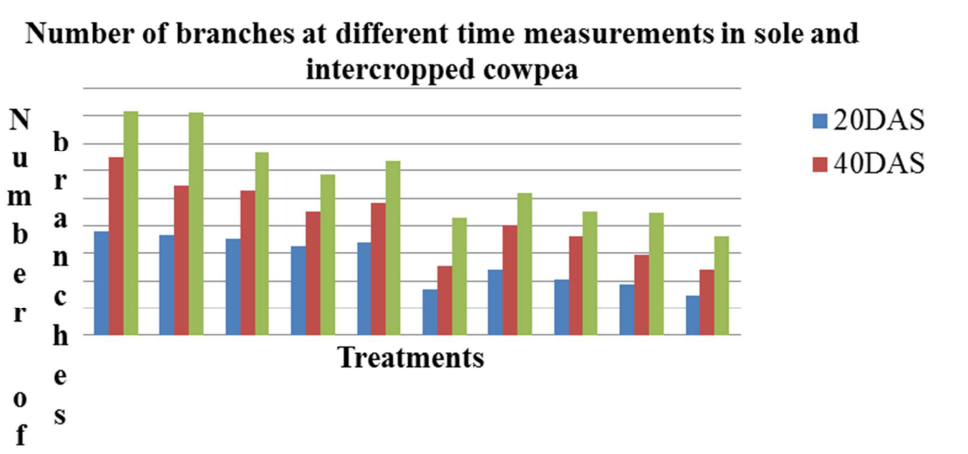

$\mathrm{T} 1=$ Sewunet, $\mathrm{T} 2=$ Bole, T3= Bekur, $\mathrm{T} 4=9333, \mathrm{~T} 5=$ local, $\mathrm{T} 6=$ Sewunet + maize, $\mathrm{T} 7=\mathrm{Bole}+$ maize, $\mathrm{T} 8=\mathrm{Bekur}+\mathrm{maize}, \mathrm{T} 9=9333+\mathrm{maize}, \mathrm{T} 10=$ local + maize

Figure 3. Cowpea plant height, numbers of leaves and numbers of branches at different time measurements in sole and intercropped with maize.

\subsection{Phonological Parameters of Cowpea}

\subsubsection{Days to 50\% Flowering}

Days to $50 \%$ flowering showed significant difference $(\mathrm{P}<0.05)$ between varieties and cropping system (Table 3$)$. Bole variety flowered early in both mono-cropped (49.67 days) and cowpea maize based cropped (55.33 days) whereas, Sewunet variety flowered late (62.67days) for mono-cultured and cowpea maize based cropped (66.67days). The difference in 50\% flowering between the study cowpea varieties might be due to varietal difference.

In case of sole cowpea cultivated, the results for days $50 \%$ flowering was higher than the result reported by Cobbinah who found an average results of 39.5 days to reach $50 \%$ flowering for cowpea genotypes in Ghana [12]. Contrary to this, the average result for $50 \%$ flowering (56.73) was lower than reported by Bilatu and Rao and Shahid who found an average results of 63 and 63.7 days, respectively, possibly due to ecological and genetic differences $[10,35]$.

The Variability between treatments in $50 \%$ flowering was in agreement with the findings of Obadoni who reported that cowpea varieties varied in number of days to $50 \%$ flowering [34]. Yohana Reported that, time taken for flowering varied from 50.67 to 70.17 days under Nigerian condition [42]. Cowpea varieties with shorter number of days to flowering and growth such as Bole are considered to be well adapted under rain fed conditions because of their ability to sustain drought, especially in the early stages of vegetative growth and for escaping late drought by maturing early.

Intercropping also delayed flowering compared to sole cropping. The shading by maize under intercropping plots caused delay in days to $50 \%$ flowering. The delay in cowpea flowering under intercropping conditions could have been influenced by the sensitivity of cowpea cultivars to light where there is a reduced day length because of taller maize plants. This result agreed with the finding of Thobatsi who reported that, intercropping delayed cowpea flowering compared to sole cropping [39]. Similar results are also reported by Moriri who reported cowpeas that are planted in intercropping flower later than those in mono crops [31]. This differs from the results of Mpangane who reported no significant differences in terms of flowering and maturity of cowpea cultivars under intercropping [32].

\subsubsection{Days to Pod Setting}

There was significant difference $(\mathrm{P}<0.05)$ between varieties and cropping system in days to pod setting (Table 3 ). Bole variety had early pod setting both under sole (57.67) and maize intercropping (62.33), whereas, sewunet variety was late pod setting under sole (70.00) and when intercropped with maize (73.33). The variability in days to pod setting when cowpea mono-cropped might be attributed to varietal variability. The present finding was in agreement with the report of Yoseph who reported that day to pod setting was significantly $(\mathrm{P}<0.05)$ affected by varieties [43]. In line with this result, Elawad also stated that Cultivar had significant effect on phonological characters. Intercropping delayed days to pod setting [15]. The delay in cowpea pod setting under intercropping conditions could have been influenced by the sensitivity of cowpea cultivars to light where there is a reduced day length because of taller maize plants.

\subsubsection{Date of Maturity}

Analysis of variance showed that there is significant difference $(\mathrm{P}<0.05)$ in days to maturity between varieties and cropping system (Table 3 ). Bole variety was early matured in both sole (83.67 days) and maize intercropping (88.33 days), whereas, sewunet variety was late matured under sole (98.33 days) and when intercropped with maize (106 days). However, in the result of present study, statistically there was no significant different between Bole, Bekur and local and similarly there were no significant different between Bekur, 9333 and local under mono-cropping cowpea varieties respectively.

Similar result was found by Amanullah who found significant variations for those 20 genotypes of cowpea he studied in days to maturity under the climatic condition of Peshawar [7]. However, in all treatment sole cropped cowpeas showed early maturity when compared to cowpea maize intercropped. Hence, intercropping delayed cowpea maturity. The present finding is in agreement with the finding of Thobatsi who concluded his result that intercropping delays physiological maturity under water limited conditions [39]. The earlier physiological maturity of cowpea planted on mono-cropping system also confirms the statements by 
Moriri that sole cowpea reached physiological maturity earlier than those planted in intercropping [31]. Cowpea phonological performances are presented in the following (Table 3).

Table 3. Phonological performance of different cowpea varieties in sole and intercropped.

\begin{tabular}{llll}
\hline Treatments & $\begin{array}{l}\text { Days of 50\% } \\
\text { flowering }\end{array}$ & $\begin{array}{l}\text { Days of pod } \\
\text { setting }\end{array}$ & $\begin{array}{l}\text { Days of } \\
\text { maturity }\end{array}$ \\
\hline T1 & $62.67 \pm 0.33^{\mathrm{b}}$ & $70.00 \pm 0.58^{\mathrm{b}}$ & $98.33 \pm 1.86^{\mathrm{b}}$ \\
$\mathrm{T} 2$ & $49.67 \pm 0.88^{\mathrm{f}}$ & $57.67 \pm 0.88^{\mathrm{e}}$ & $83.67 \pm 0.88^{\mathrm{f}}$ \\
$\mathrm{T} 3$ & $51.67 \pm 1.45^{\text {ef }}$ & $60.00 \pm 1.73^{\mathrm{de}}$ & $86.33 \pm 0.88^{\text {ef }}$ \\
T4 & $53.00 \pm 0.58^{\mathrm{e}}$ & $61.00 \pm 0.58^{\mathrm{d}}$ & $87.33 \pm 0.88^{\mathrm{e}}$ \\
$\mathrm{T} 5$ & $53.00 \pm 0.58^{\mathrm{e}}$ & $61.00 \pm 1.15^{\mathrm{d}}$ & $86.33 \pm 0.88^{\text {ef }}$ \\
T6 & $66.67 \pm 0.33^{\mathrm{a}}$ & $73.33 \pm 0.88^{\mathrm{a}}$ & $106.00 \pm 1.5^{\mathrm{a}}$ \\
T7 & $55.33 \pm 0.67^{\mathrm{d}}$ & $62.33 \pm 0.33^{\mathrm{d}}$ & $88.33 \pm 0.88^{\mathrm{de}}$ \\
T8 & $57.67 \pm 0.33^{\mathrm{c}}$ & $65.33 \pm 0.67^{\mathrm{c}}$ & $91.00 \pm 0.58^{\text {cd }}$ \\
T9 & $58.33 \pm 0.33^{\mathrm{c}}$ & $66.67 \pm 0.33^{\mathrm{c}}$ & $92.67 \pm 0.88^{\mathrm{c}}$ \\
T10 & $59.33 \pm 0.67^{\mathrm{c}}$ & $67.00 \pm 0.58^{\mathrm{c}}$ & $92.33 \pm 1.20^{\mathrm{c}}$ \\
Mean & $56.73 \pm 0.62$ & $64.44 \pm 0.77^{2}$ & $91.23 \pm 1.04$ \\
P-value & $<0.0001$ & $<0.0001$ & $<0.0001$ \\
\hline
\end{tabular}

Means with the same letter in the same column are not significantly different $(\alpha=0.05)$.

$\mathrm{T} 1=$ Sewunet, $\mathrm{T} 2=$ Bole, $\mathrm{T} 3=$ Bekur, $\mathrm{T} 4=9333$, T5=local, $\mathrm{T} 6=$ Sewunet + maize, $\mathrm{T} 7=$ Bole + maize, $\mathrm{T} 8=$ Bekur + maize, $\mathrm{T} 9=9333+$ maize, $\mathrm{T} 10=$ local + maize .

\section{Conclusion}

The current study revealed that the tested cowpea varieties can adapt well to the agro-ecological condition of Chewaka district with high levels of germination and vigor. However, different cowpea varieties responded with different growth performance when cultivated at sole and intercropped with maize. Considerable variation exists among the tested varieties, indicating the potential for selecting superior genotypes for both forage and grain yield (dual purpose). The highest growth performance in both sole cropped and intercropped with maize was obtained from Bole variety. Bole variety recorded the highest number of leaves/plant, the highest number of branch/plant in both sole and intercropped with maize. Sewunet variety showed a good performance only in plant height and number of leaves/plant in sole cropped but, could not be compatible with maize at under sown cowpea for both herbage and grain yield. Earlier 50\% flowering, pod setting and maturity was found in Bole in sole and mixed cropping. Intercropping can reduce growth performances of cowpea in all treatments. However, intercropping increased the biological productivity of land than sole cropping system. Therefore, forage development strategy like intercropping of cowpea forage in maize crops is the most important option to solve animal feed and land shortage as well as improve soil fertility to ensure crop productivity in the study area.

\section{Recommendation}

Dual purpose cowpea species are the appropriate crops and recommended for the chewaka district where the land situation is small and mixed crop livestock farming system is practiced. On the other hand, awareness creation at farmer level is needed on integrated improved forage development strategies by different stake holders in the district.

Further study is also important to see the effects of feeding cowpea forages on animal performance and to identify the level of inclusion in various ruminants' rations.

\section{References}

[1] Abera M., 2014. The Effect of Under Sowing of Forage Legumes in Maize on Dry Matter Yield and Nutritional Value of the Fodder in Baresa Watershed, Ethiopia. International Journal of Science and Research (IJSR), 3: 3.

[2] Aikins. SHM, Afuakwa JJ 2008. Growth and dry matter yield responses of cowpea to different sowing depths. ARPN. J. Agric. Biolo. Sci., 3 (5\&6): September-November.

[3] Akande, S. R. 2007. Biplot analysis of genotype by environment interaction of cowpea grain yield in Forest and Southern Guinea Savanna Agro-ecologies of Nigeria. Journal of Food, Agriculture and Environment. 5: 464-467.

[4] Aklilu, M and Alemayehu M. 2007. Measurements in pasture and forage cropping systems. Technical manual 18. Ethiopian Agricultural Research Institute.

[5] Ali, B. Izge, A. U. Odo, P. E and D. Aminu., 2009. Varietal Performance of Dual Purpose Dry Season Cowpea (Vigna unguiculata L. Walp) under Varying Plant Spacing in the Fadama in North Eastern Nigeria. American-Eurasian Journal of Sustainable Agriculture 3: 13-18.

[6] Aliyu, B. S. and Emechebe, A. M., 2006. Effect of Intra- and inter-row mixing of sorghum with two varieties of cowpea on host crop yield in a Striga hermonthica infested field. African Journal of Agricultural Research, 1 (2): 24-26.

[7] Amanullah, Hatam M and Ahmad N 2000. Performance and distinguishing characters of promising cowpea germplasm. Sarhad J of Agric 16 (4): 365-369.

[8] Anjum Ahmad, Gajendra Singh Tomar, Sudhir Kumar Taunk and Nidhi Verma., 2017. Evaluation of New Cultivars of Fodder Cowpea in Terms of Growth Attributes and Seed Yield as Influenced by Various Doses and Varieties. Int. J. Curr. Microbiol. App. Sci. 6 (10): 937-944.

[9] Ayana E, Estefanos T, Ashenafi M, Abubeker H., 2013. Advanced evaluation of cowpea (Vigna unguiculata) accessions for fodder production in the central rift valley of Ethiopia. Journal of Agricultural Extension and Rural Development Vol. 5 (3), pp. 5561.

[10] Bilatu A., Binyam K., Solomon Z., Eskinder A. and Ferede A., 2012. Animal feed potential and adaptability of some cowpea (Vigna unguiculata) varieties in North West lowlands of Ethiopia. Wudpecker Journal of Agricultural Research 1 (11): 478 - 483. 103 - 109.

[11] CDOARD (Chewaka District Office of Agriculture, and Rural Development) 2017. Annual report, Chewaka.

[12] Cobbinah, F. A. Addo-Quaye, A. A. and I. K. Asante., 2011. Characterization, evaluation and selection of cowpea (Vigna unguiculata (L.) Walp) accessions with desirable traits from eight regions of Ghana. Journal of Agricultural and Biological Science 6: 21-32. 
[13] CSA (Central Statistical Authority), 2016. Agricultural sample survey report on livestock and livestock characteristics, volume II, Addis Ababa, Ethiopia.

[14] Egbe, O. M., Alibo, S. E. and Nwueze, I., 2010. Evaluation of some extra-early and early-maturity cowpea varieties for intercropping with maize in Southern Guinea for intercropping with maize in Southern Guinea Savanna of Nigeria. Agricultural and Biology Journal of North America 1 (5): 845-858.

[15] Elawad, H. O., 2000. The performance of selected cowpea (Vigna unguiculata L. Walp). Varieties in the sandy rainfed areas of Kordofan. Agricultural Research Corporation, Elobied, Sudan.

[16] Eskandari H., Ghanbari, A., 2010. Environmental resource consumption in wheat and bean intercropping: Comparison of nutrient uptake and light interception. Notulae Scientia Biologicae, 2 (3): 100-103.

[17] Fekede F., 2004. Evaluation of potential forage production qualities of selected oats (Avenasativa L.) genotypes. M. Sc. Thesis. Alemaya University of Agriculture, Ethiopia.

[18] Gabir, N. M., 1997. The effect of intercropping on growth and yield of sorghum (Sorghum bicolor (L. Moench.). M. Sc. Thesis. University of Zalingie, pp 60.

[19] Getnet A., Inger L., 2001. Effect of variety, soil type and fertilizer on the establishment, growth, forage yield, quality and voluntary intake by cattle of oats and vetches cultivated in pure stands and mixtures, Animal Feed Science and Technology. 92: 95-111.

[20] Hailemariam, F. B. 2014. Agronomic practices, yield, chemical compositionand in vitro dry matter digestibility of sudangrass (sorghum sudanese 1.) mixed with lablab (lablab purpureus 1.) and cowpea (Vigna unguiculata 1.) at Babile, Eastern Ethiopia. Msc, thesis, pp 23. Haramaya University, Ethiopia.

[21] Hamd Alla WA, Shalaby EM, Dawood RA, Zohry AA., 2014. Effect of cowpea (Vigna sinensis L.) with maize (Zea mays L.) intercropping on yield and its components. Int. J. Biol. Biomed. Agric. Food Biotechnol. Eng. 8 (11): 1258-1264.

[22] Haruna, I. M., and Usman, A., 2013. Agronomic efficiency of cowpea varieties (Vigna unguiculata (L.) Walp) under varying phosphorus rates in Lafia, Nassarawa state, Nigeria. Asian $J$. Of Crop Sci., 5: 209-215.

[23] Hauggaard-Nielsen H, B. Jørnsgaard, J. Kinane and E. S. Jensen., 2008. Grain legume-cereal intercropping: The practical application of diversity, competition and facilitation in arable and organic cropping systems. Renewable Agriculture and Food Systems: 23 (1): 3-12.

[24] Hayder Ghulam, S., Suhail Mumtaz, Aslam Khan, Sherin Khan., 2003. Maize and Soybean Intercropping under Various Levels of Soybean Seed Rates. Asian Journal of Plant Science, 2 (3): 339-341.

[25] Ichi, J. O., Igbadun, H. E., Miko, S. and Samndi, A. M., 2013. Growth and yield response of selected cowpea (Vigna unguiculata (L.) Walp) varieties to irrigation interval and sowing date. The Pacific J. Sci. \& Technol. 14 (1): 453-463.

[26] Kelechukwu, N. E., Adewale, M. O. and Ezekial, A. A., 2007. Aluminium, influence on performance of some cowpea (Vigna unguiculata) varieties on Nigeria Alfisol. World J. Agric. Sci., 3 (4): 512-522.
[27] Koralagama K. D. N., J. Hanson, D. I. Givens, P. Q. Crauford, F. L. Mould and S. Fernandez-Rivera, 2005. Cowpea (Vigna unguiculata) as a human food and ruminant forage crop for small holders in Ethiopia.

[28] Liu, J. H., Z. H. Zeng, L. X. Jiao, Y. G. Hu, Y. Wang, H. Li., 2006. Intercropping of different silage maize cultivars and alfalfa. Acta. Agron. Sci. 32: 125-130.

[29] Mapiye, C., M Mwale, J. F. Mupargwa, P. H. Mugabe, X. Poshiwa and N. Chikubmba, 2007. Utilization of ley legumes livestock feed in Zimbabwe. Tropical Grass lands 430.

[30] MoARD (Ministry of Agriculture and Rural Development), 2009. Animal and Plant Health Regulatory Directorate. Crop Variety Register, Addis Ababa, Ethiopia, p: 213.

[31] Moriri, S., Owoeye, L. G. and Mariga, I. K., 2010. Influence of component crop densities and planting patterns on maize production in dry land maize/cowpea intercropping systems. African Journal of Agricultural Research 5 (11): 1200-1207.

[32] Mpangane, P. N. Z., Ayisi, K. K., Mishiyi, M. G., and A. Whitbread., 2004. Grain yield of maize, grown in sole and binary cultures with cowpea and lablab in the Limpopo Province of South Africa. In tropical legumes for sustainable farming systems in Southern Africa and Australia. ACIAR Proceedings. 115: 106-114.

[33] Ndiso, J. B., 2015. Enhancing performance of maize-cowpea based cropping systems in coastal lowland kenya through stress resilient varieties and soil moisture conservation practices. Msc. Thesis. University of Nairobi, Kenya, pp 91.

[34] Obadoni, B. O., J. K. Mensah, and L. O. Ikem., 2000. "Varietal Response of Four Cowpea Cultivars (Vigna unguiculata L. Walp) to Different Densities of Guinea Grass (Panicum maximum)".

[35] Rao NK, Shahid M., 2011. Potential of cowpea [Vigna unguiculata (L.) Walp.] and guar [Cyamopsis tetragonoloba (L.) Taub.] as alternative forage legumes for the United Arab Emirates. Emir. J. Food Agric. 23 (2): 147-156.

[36] Sebetha, E. T., 2007. Evaluation of yield and protein content of two cowpea cultivars grown under different management practices. MSC, Thesis. University of Limpopo, pp 82.

[37] Singh, B. K., Pathak, K. A. Verma, A. K., Verma, V. K. and Deka, B. C., 2011. Effects of vermicompost, fertilizer and mulch on plant growth, nodulation and pod yield of French bean (Phaseolus vulgaris L.). Vegetable Crops Research Bulletin 74: 153 - 165 .

[38] Solomon B., Solomon M. and Alemu Y., 2008. Influence of rainfall pattern on grass/legume composition and nutritive value of natural pasture in Bale Highlands of Ethiopia. Livestock Research for Rural Development. Volume 20, Article \#38. (Accessed 20 November, 2015).

[39] Thobatsi, T., 2009. Growth and yield responses of maize (Zea mays L.) and Cowpea (Vigna unguiculata L.) in an Intercropping System. Msc. Thesis. University of Pretoria. pp. 159.

[40] Tilahun T., Minale L. and Alemayehu A., 2012. Role of maize (Zea mays L.)- fababean (Vicia faba L.) intercropping planting pattern on productivity and nitrogen use efficiency of maize in northwestern Ethiopia highlands. International Research Journals, 2 (3): 102-112. 
[41] Yayneshet T, Eik LO, Moe SR., 2009. The effects of enclosures in restoring degraded semi-arid vegetation in communal grazing lands in northern Ethiopia. Journal of Arid Environments, 73: 542-549.

[42] Yohana M., 2014. Evaluation of some cowpea (Vigna ungiculata (L.) Walp) genotypes at Mubi, in the Norther $\mathrm{n}$ Guinea Sabvanna ecology of Nigeria. The International Journal of Engineering and Science. 3 (2): 44-47.
[43] Yoseph, T., 2014. Performance Evaluation of Cowpea (Vigna unguiculata L.) Varieties Under Moisture Conservation Practices for Yield and Yield Components at Alduba, Southern Ethiopia. Journal of Natural Sciences Research. 4 (7), pp 8.

[44] Zewdie W. and Yosef M., 2014. Feed resources availability and livestock production in the central rift valley of Ethiopia. International Journal of Livestock Production. 5 (2), pp. 30 35. 